\section{AGRICULTURAL EDUCATION IN GREAT BRITAIN}

A GRICULTURAL education in rural areas of A Great Britain was the first subject for discussion at the recent conference of the Agricultural Education Association held at the Midland Agricultural College during January 4-6.

Mr. F. H. Garner prefaced his remarks by saying that the inhabitants of the countryside who are of necessity interested in agriculture are the landowner, the farmer, the farm worker and the parents of children living in the country. Little special effort has been made to educate landowners, but to a very large extent they have received information on all phases of agriculture. The older type of landlord is being replaced by a new type, such as the universities, colleges and insurance companies; the agents who manage such estates have had good training in agriculture and the results are good from the farmer's point of view.

As regards the farmers, the county councils, through the agricultural organizers and their staffs, are in the first instance primarily responsible for their education. A certain amount of work has been done by the National Farmers' Union, agricultural societies and clubs, and so on. A certain percentage of farmers have taken courses in agriculture at the universities, agricultural colleges and institutes. About two years after the outbreak of war, the War Agricultural Executive Committees took over much of the educational work in agriculture through their technical development sub-committees, and in many cases the work was carried out on a much wider scale than had been possible hitherto. These sub-committees could be very active because money was made available for educational work; they were helped by the fact that farmers were getting better prices and consequently could try out recommendations. They have done more to push forward the education of backward farmers than has ever been accomplished before, and it seems most important that such work should be maintained in peace-time. During the last few years, an agricultural bias has been introduced into the teaching at many rural schools, and the Young Farmers' Club movement is extending rapidly; it can be stated that in various ways farmers are receiving an agricultural education.

On the other hand, there has been very little attempt to provide agricultural education or instruction for farm workers. There have been a few short courses at agricultural institutes, but generally farm workers have received very little education in rural matters. More recently, but only to a limited extent, some of the demonstrations run by the War Agricultural Committees have been staged to attract the agricultural worker, Sometimes the workers show no inclination to attend the demonstrations, and there is the added difficulty that these workers, having to earn their livings on the land, are unable to attend if loss of wages results, except perhaps on Saturday afternoons. Demonstrations must be specially planned for the workers, and farmers must be approached in order that they may encourage their men to attend. Also, the farm institute courses for the young farm worker must be reintroduced, and this despite the danger that after these young people have attended their courses they may try to leave the land and obtain more remunerative posts.

With regard to the parents of the country school children : these parents may have various interests, for they may not all be agricultural workers. In the past, this section of the community has received no agricultural education of any kind, and it is quite evident that parents can undo all the good work done by schools, Young Farmers' Clubs, county councils, etc., in maintaining interest in rural activities. Before parents will encourage their children to work on farms they must first be satisfied that housing in rural areas is as good as it is in towns, and that their children can find adequate recreation, both indoors and outdoors, in the villages; that their children will earn as much money on the land as in the town ; and that agricultural work is not degrading. Something must also be done to appeal to wives and prospective wives of the farm worker. The courses given in rural schools on domestic science, dressmaking and hygiene are very valuable, but if the girls find that housing conditions in rural areas make it difficult, and sometimes impossible, for them to do as they have been taught, they may be forced, through education, to find houses in the towns.

The ensuing discussion had a very wide range, for several speakers felt that in the matter of agriculture it is not possible to separate rural from urban educa. tion. Mr. S. J. Travers, of Kent, believes that urban and rural children should be educated together: they would be on the right lines if they could be made to understand that the land is a national asset and not to be abused as it had been in the past. It was pointed out by Mr. R. H. Smith, Hampshire, that whereas the rural child, through scholarships, etc., has the beginning of a ladder, the urban child has no means at all of obtaining the first steps in agricultural education. Town boys who are eager to take up agriculture may have their enthusiasm killed by being placed in unsuitable work on unsuitable farms. Other speakers also mentioned this question of a 'ladder'. Principal Robinson, Midland Agricultural College, referred to the need for an agricultural education which would give encouragement to the man with ability but lacking the capital to advance up the ladder. He thought a rural bias could well be introduced into education, not so that plenty of skilled labour would be available for the farmer, but to enable even the town boy or girl to appreciate and understand countryside problems. The cry in the past has been cheap food and hang the farmer : unless we educate the rural with the non-rural community, we shall not achieve this appreciation.

The opinion that teachers generally should be educated to the importance of agriculture as an industry was voiced by Mr. W. R. Heaton, Burford Grammar School, who complained that very little financial support is forthcoming for any scheme in agricultural education. He stressed that vocational agriculture should not be taught in schools, but instruction should be given in the underlying fundamentals of biology, chemistry of soils, and some book-keeping and mathematics done from mensuration of farm buildings, etc.

After several members had contributed to the discussion, Mr. John Davies, Glamorgan, remarked that the scope was for ever widening as each speaker seemed anxious to educate yet another class of people. He then asked: Whom do we wish to educate? He believed that the farmer and the farming community are entitled to first consideration, and this opinion was warmly supported by Mr. A. McVicar, Shropshire, and Mr. E. Rea. Mr. McVicar and others said that there is no recognized plan or 
scheme for a system of agricultural education in Great Britain, and this is urgently needed. It was suggested by Mr. F. R. Horne, of Devon, that not enough attention has been paid to following up the careers of the more promising trainees to see that they become established in agriculture.

The technical development sub-committees referred to in Mr. Garner's paper were both criticized and praised. They were spoken of as an implied criticism of pre-war policy in agricultural education, because if this had not been neglected in pre-war years, there would not now be the necessity for forming these committees. The work of these committees was also stated not to be fundamental education but rather 'tip-giving'. On the other hand, the expansion of agricultural education through the committees as a national charge was welcomed, and it was urged that if they are to continue after the War they must be moulded on the right lines now.

A statement by Mr. R. C. Andrew on the Danish system of education for older people caused Mr. R. C. Wood to urge his hearers to familiarize themselves with the writings of Sir Richard Livingstone on the Danish folk high schools. More attention must be paid to adult education and a more cultural atmosphere should be introduced into agricultural institutions in Great Britain.

\section{NORTH SYRIA AS A CULTURAL LINK IN THE ANCIENT WORLD}

$\mathrm{T}$ HE subject chosen by Sir Leonard Woolley for his Huxley Memorial Lecture delivered on November 24 before the Royal Anthropological Institute was the role played by north-west Syria in the first and second millennia B.C. as a connecting link between the civilizations of the Near and Middle East. The region is defined as the area stretching from Lattakia on the present north Syrian coast northwards to the Anti-Taurus Range, and from the Mediterranean Sea to Aleppo. To the south and south-east lay "the commercial kingdoms of Syria and the Phoenician harbours", with Egypt still farther to the south: eastwards lay the homes of the Amorites and the Khurri, leading on to Nineveh. The Euphrates leads direct to Babylon or northeastwards to the region of Lake Van and the Uratu kingdom; northwards beyond the mountain barriers lay Cappadocia and the Konia plain, leading to the Bosphorus or the Ionian coast; westwards were Crete and Greece, with Cyprus-actually visible from the top of Mount Casius - as a stepping-stone. The nodal position of the region thus chosen is obvious.

Before the War, three main excavations of special interest from Sir Leonard's point of view were in progress: Ras Shamra, just north of Lattakia, the ancient royal city of Ugarit; Al Mina. at the mouth of the Orontes, and the Atchana mound, up the Orontes on the edge of the great Amk plain ; and Tal Tayanat, where the Oriental Institute of Chicago has excavated the Syro-Hittite palace. Other recent excavations there have of course been in the Amk plain, and also farther north-westwards as at Mersin on the Cilician coast, but Sir Leonard in the limited time available confined himself principally to the results of his own work at Atchana where, too, the chronological framework devised by Prof. Sidney
Smith in his monograph "Alalakh and Chronology" provided him with a gratefully accepted method of correlation with better known cultures in neighbouring lands.

At Alalakh (the Atchana mound) there were unearthed seven archæological levels of buildings, pottery, etc., and a trial pit has shown at least three more underneath and as yet unexcavated. Layer 7 has yielded an imposing city gate and a great palace built by Yarim Lim, king of Aleppo and overlord of Alalakh-according to Sidney Smith c. 1780-1730 B.c. It is contemporary, therefore, with the end of the Egyptian Twelfth Dynasty and the Middle Minoan period of Crete. Near the coast at Ras Shamra, Middle Minoan II sherds have been discovered in presumably contemporary levels but, of course, this does not itself prove direct contacts. No Cretan ware occurred at Alalakh ; all was Asiatic (Khabur ware), and the types persisted down to level 5, c. 1483 B.c. During 1800-1500 B.c. Alalakh was thus predominantly Amorite. There is evidence (seal-impressions) that Egyptian political claims were recognized, but culturally the town looked eastwards. But while the influence of the West on Alalakh seems at this time to have been slight, Sir Leonard feels that the astonishing resemblance of the palace itself in its plan and construction to that of Knossos, not to mention the style of the frescoes found, suggests, even as Sir Arthur Evans hinted ("Palace of Minos", 2, 269) that migration of Asiatic people to Crete played a part in the rise of the culture there. He adds that the frescoes at Alalakh are at least a century older than their parallels at Knossos, so that "there can be little doubt as to the originating centre", and argues that North Syria was helping to build up in Crete that remarkable Minoan civilization which was later to have its repercussions in Asia. In the same way and on the same grounds of architectural resemblances, he suggests that Amorite influence affected the regions to the north, inspiring not only the late Syro-Hittite buildings of North Syria such as Sakje-Geuzi and Carchemish, but even the more distant Boghaz Keui in the Halys basin.

In levels 6 and 5 there are fewer remains. It would seem that the influence of Egypt disappeared-this was the period of the Hyksos domination there-but the Hittites to the north were becoming an organized power. It was a Hittite invasion of North Syria, conducted by Mursil I in 1595, that terminated the local phase represented by level 6. However, culturally Alalakh continued much as before until Thutmose III conquered the town in 1483. But the weakness of Egypt permitted the folk of the 6th level to be in closer relationship with southern Syria and Palestine, as is reflected in the types of pottery found.

Level 4, starting from the Egyptian campaign of 1483, comprises, in so far as its principal building is concerned, three phases, including the enlarged palace of Niqme-Pa, c. 1450, which take us down to 1370, when the Hittite king Suppiluliuma invaded North Syria and, after destroying the Mitanni kingdom, installed his son as king of Aleppo. The main feature of the pottery of level 4 is the prevalence of the Cypriote Bronze Age type. Gone is the old Khabur ware. The better local wares are now either plain burnished red, or have simple bands of colour. All have a distinctly Cypriote flavour. As the typical Cypriote 'milk bowl' actually occurs at Alalakh so early as level 6 (seventeenth century B.c.) and sherds resembling the Cypriote white slip ware have been 